\title{
AKUMULASI MERKURI (Hg) PADA IKAN DI TELUK MANADO
}

\author{
(Mercury Accumulation ( $\mathrm{Hg})$ in Fish of Manado)
}

\author{
Alen Angelina Narasiang ${ }^{{ }^{\star}}$, Markus T. Lasut ${ }^{1}$, Nikson J. Kawung ${ }^{1}$
}

1. Program Studi IImu Kelautan, Fakultas Perikanan dan IImu Kelautan, Universitas Sam Ratulangi, Manado

*e-mail: alenangelinanarasiang@yahoo.com

Harmful heavy metals in waters directly to living organisms, as well as indirect effects on human health. This study aims to measure and compare the concentrations of mercury $(\mathrm{Hg})$ in several species of fish, as well as determining the accumulation of mercury in fish that live in the waters of the Bay of Manado. Sampling was conducted in fish at two locations, namely the Southern and Northern parts of the waters in the Bay of Manado. Samples obtained from the fishermen catch fish by means capture directly. Samples were taken from each of every location has 9 individual, which consists of 3 types of fish with 3 replications. Samples of fish were chosen to have the same relative size range for each type of fish. Samples are identified and analyzed further to the Research and Industrial Standards (Baristand) Manado. Inspection method using Atomic Absorption Spectrometer instrument (SSA). The highest mercury found in fish Gora (Myripritis hexagona) with an average value of 0:43 ppm, and the second highest value is on Capungan fish (Apogon compresseus) with an average value of $0.3 \mathrm{ppm}$, while the lowest value contained in the yellow baronang fish (Siganus virgatus) with an average value of $0.1 \mathrm{ppm}$. The concentration of mercury $(\mathrm{Hg})$, the highest found in fish from Southern locations (Bay of Manado), compared to the same type of the Northern (Bay of Manado).

Keywords : Levels mekuri $(\mathrm{Hg})$, bioaccumulation, food chain, fish Gora (Myripritis hexagona), Baronang fish (Siganus virgatus), Capungan fish (Apogon compressus)

Logam berat di perairan berbahaya secara langsung terhadap kehidupan organisme, maupun efeknya secara tidak langsung terhadap kesehatan manusia. Penelitian ini bertujuan untuk mengukur dan membandingkan konsentrasi merkuri $(\mathrm{Hg})$ pada beberapa jenis ikan, serta menentukan akumulasi merkuri pada ikan yang hidup di perairan Teluk Manado. Pengambilan sampel ikan dilakukan di 2 (dua) lokasi, yaitu bagian Selatan dan bagian Utara dari perairan Teluk Manado. Sampel ikan diperoleh dari tangkapan nelayan dengan cara menangkap langsung. Sampel yang diambil dari masing-masing dari setiap lokasi berjumlah 9 individu, yang terdiri atas 3 jenis ikan dengan 3 ulangan. Sampel ikan yang dipilih memiliki kisaran ukuran yang relatif sama untuk masing-masing jenis ikan. Sampel diidentifikasi dan dianalisis lanjut ke Balai Riset dan Standarisasi Industri (Baristand) Manado. Metode pemeriksaan menggunakan alat Spektrometer Serapan Atom (SSA). Merkuri tertinggi ditemukan pada ikan Gora (Myripritis hexagona) dengan nilai rata-rata 0.43 ppm, dan nilai tertinggi kedua yaitu pada ikan Capungan (Apogon compresseus) dengan nilai rata-rata $0.3 \mathrm{ppm}$, sedangkan nilai terendah terdapat pada ikan Baronang kuning (Siganus virgatus) dengan nilai rata-rata $0.1 \mathrm{ppm}$. Konsentrasi merkuri $(\mathrm{Hg})$ tertinggi ditemukan pada ikan dari lokasi bagian Selatan (Teluk Manado), dibandingkan pada jenis yang sama dari bagian Utara (Teluk Manado).

Kata kunci : Kadar mekuri $(\mathrm{Hg})$, bioakumulasi, rantai makanan, ikan Gora (Myripritis hexagona), ikan Baronang (Siganus virgatus), ikan Capungan (Apogon compressus) 


\section{PENDAHULUAN}

Masalah lingkungan hidup merupakan prioritas mutlak dipecahkan bagi semua Negara, termasuk Indonesia. Seiring dengan perkembangan teknologi dan industri, selain membawa keuntungan dengan peningkatan kesejahteraan manusia, juga membawa masalah yakni dampak lingkungan dari limbah yang dihasilkan. Padahal, lingkungan mempunyai peran penting bagi kehidupan manusia. Menurut Ridhowati (2013), proses pencemaran dapat terjadi secara langsung maupun tidak langsung. Secara langsung, yaitu bahan pencemar langsung berdampak meracuni sehingga mengganggu kesehatan manusia, hewan, dan tumbuhan atau mengganggu keseimbangan ekologis air, udara, maupun tanah. Proses tidak langsung, yaitu beberapa zat kimia bereaksi di udara, air, maupun tanah, sehingga menyebabkan pencemaran. Berdasarkan sifat kimia dan fisik, tingkat atau daya racun logam berat terhadap hewan air secara berurutan adalah merkuri $(\mathrm{Hg})$, kandium $(\mathrm{Cd})$, seng $(\mathrm{Zn})$, timah hitam $(\mathrm{Pb})$, krom $(\mathrm{Cr})$, nikel ((Ni), dan kobalt (Co). Apabila merkuri masuk ke lingkungan perairan akan berikatan dengan klor yang ada dalam air laut membentuk ikatan $\mathrm{HgCl}$. Dalam bentuk tersebut $\mathrm{Hg}$ mudah masuk ke dalam plankton dan berpindah ke biota lain (Widowati dkk., 2008).

Manusia dapat terakumulasi merkuri melalui konsumsi makanan yang tercemar, ikan dan kerang. Senyawa merkuri yang ditemukan dalam jaringan ikan adalah $\mathrm{Me}-\mathrm{Hg}$ yang berkonsentrasi tinggi, yang merupakan hasil dari biomaknifikasi melalui interaksi tingkat tropik dalam rantai makanan. Jumlah merkuri yang terakumulasi dalam ikan atau kerang tergantung pada siklus geokimia yang ada (Fahruddin, 2010). Perairan Teluk Manado merupakan perairan yang memiliki tingkat aktivitas manusia yang cukup tinggi, misalnya: penangkapan ikan, transportasi, dan parawisata. Kondisi perairan Teluk Manado berpotensi terkontaminasi dengan bahan-bahan pencemar seperti logam merkuri $(\mathrm{Hg})$ yang sangat berbahaya bagi biota-biota yang hidup dalam perairan tersebut, bahkan secara tidak langsung mempengaruhi kesehatan manusia. Mengingat pengaruh toksik yang dapat ditimbulkan oleh logam merkuri $(\mathrm{Hg})$ dan belum tersedianya informasi mengenai keberadaan logam merkuri $(\mathrm{Hg})$ pada beberapa jenis ikan sebagai bioindikator pencemaran di wilayah perairan Teluk Manado, maka penelitian ini dilakukan. Penelitian ini bertujuan untuk mengukur dan membandingkan konsentrasi merkuri pada beberapa jenis ikan, serta menentukan akumulasi merkuri pada ikan yang hidup di perairan Teluk Manado.

\section{METODE PENELITIAN}

Pengambilan sampel ikan dilakukan di 2 (dua) lokasi, yaitu bagian Selatan (Malalayang) dan bagian Utara (Bailang) dari perairan Teluk Manado. Sampel ikan diperolah dari tangkapan nelayan dengan cara menjubi atau/ menangkap langsung. Sampel yang diambil dari masing-masing dari setiap lokasi berjumlah 9 individu, yang terdiri atas 3 jenis ikan dengan 3 ulangan. Sampel ikan yang dipilih memiliki kisaran ukuran yang relatif sama untuk masingmasing jenis ikan. Ikan-ikan yang diperoleh disimpan dalam cool box yang telah berisi es batu, selanjutnya sampel diidentifikasi dan dianalisis lanjut ke Balai Riset dan Standarisasi Industri (Baristand) Manado.

Penentuan kandungan merkuri $\mathrm{Hg}$ dengan mengacu Standar Nasional dan panduan Indonesia (SNI) 01-28961992 dan panduan Balai Riset dan 
Standarisasi Industri (Anonimous, 2011). Secara singkat prosedur pengukuran tersebut didahului dengan proses destruksi sampel dimana $0,5 \mathrm{~g}$ sampel dimasukan ke dalam labu ukur kemudian ditambahkan Aquades sebanyak $2 \mathrm{ml}$ dan $2 \mathrm{ml} \mathrm{HNO}$. $\mathrm{HClO}_{4}$ (1:1) dan $5 \mathrm{ml}$ $\mathrm{H}_{2} \mathrm{SO}_{4}$ kemudian dipanaskan di atas hotplate pada suhu $200{ }^{\circ} \mathrm{C}$ selama 30 menit. Sampel didinginkan hingga temperatur ruangan dan kemudian ditambahkan aquades sebanyak $50 \mathrm{ml}$ dan $5 \mathrm{ml} \quad \mathrm{SnCl}_{2}$. Sampel dianalisis menggunakan alat Spektrometer Serapan Atom (SSA). Analisis data disajikan secara statistik deskriptif dengan mengambarkan data hasil analisis baik dalam bentuk tabel ataupun grafik.

\section{HASIL DAN PEMBAHASAN}

Sampel ikan yang ditangkap di Selatan dan Utara dari perairan Teluk Manado setelah diseleksi dan diidentifikasi, terdiri dari 3 jenis ikan yaitu: Ikan Gora (Myripritis hexagona), ikan Beronang kuning (siganus virgatus), dan ikan Capungan (Apogon compressus). Data jenis ikan sampel yang ditangkap telah diidentifikasi, dan disajikan dalam Tabel 1. Tabel 2 menampilkan hasil pengukuran konsentrasi merkuri $(\mathrm{Hg})$ dari sampel ikan yang ditangkap dari perairan Teluk Manado.

Tabel 1. Jenis Ikan Sampel yang diidentifikasi di Perairan Teluk Manado (TM).

\begin{tabular}{|c|c|c|c|c|c|}
\hline Jenis Ikan & $\begin{array}{c}\text { Lokasi } \\
\text { Pengambilan } \\
\text { Sampel }\end{array}$ & $\begin{array}{l}\text { Jumlah } \\
\text { Sampel }\end{array}$ & $\begin{array}{l}\text { Panjang } \\
\text { Total } \\
\text { (cm) }\end{array}$ & $\begin{array}{l}\text { Berat Total } \\
\quad \text { (gram) }\end{array}$ & $\begin{array}{l}\text { Posisi Dalam } \\
\text { Rantai } \\
\text { Makanan }\end{array}$ \\
\hline \multirow{3}{*}{ Gora } & \multirow{3}{*}{ Selatan TM } & \multirow{3}{*}{3} & 13 & 105 & \multirow{3}{*}{ Karnivora } \\
\hline & & & 16,2 & 114 & \\
\hline & & & 13,5 & 55 & \\
\hline \multirow{3}{*}{$\begin{array}{c}\text { Baronang } \\
\text { kuning }\end{array}$} & \multirow{3}{*}{ Selatan TM } & \multirow{3}{*}{3} & 20 & 184 & \multirow{3}{*}{ Herbivora } \\
\hline & & & 20,5 & 184 & \\
\hline & & & 20,4 & 185 & \\
\hline \multirow{3}{*}{ Capungan } & \multirow{3}{*}{ Selatan TM } & \multirow{3}{*}{3} & 12 & 21 & \multirow{3}{*}{ Karnivora } \\
\hline & & & 12,5 & 28 & \\
\hline & & & 14,1 & 32 & \\
\hline \multirow{3}{*}{ Gora } & \multirow{3}{*}{ Utara TM } & \multirow{3}{*}{3} & 17,7 & 105 & \multirow{3}{*}{ Karnivora } \\
\hline & & & 17,7 & 114 & \\
\hline & & & 13,6 & 55 & \\
\hline \multirow{3}{*}{$\begin{array}{c}\text { Baronang } \\
\text { kuning }\end{array}$} & \multirow{3}{*}{ Utara TM } & \multirow{3}{*}{3} & 20,4 & 184 & \multirow{3}{*}{ Herbivora } \\
\hline & & & 18,3 & 183 & \\
\hline & & & 20,5 & 184 & \\
\hline \multirow{3}{*}{ Capungan } & \multirow{3}{*}{ Utara TM } & \multirow{3}{*}{3} & 12,8 & 32 & \multirow{3}{*}{ Karnivora } \\
\hline & & & 12,3 & 28 & \\
\hline & & & 11 & 21 & \\
\hline
\end{tabular}


Tabel 2. Konsentrasi Merkuri Pada Ikan di Teluk Manado (TM).

\begin{tabular}{|c|c|c|c|}
\hline Lokasi & Jenis Ikan & Ulangan & Konsentrasi $\mathrm{Hg}$ (ppm) \\
\hline \multirow{9}{*}{ Selatan TM } & \multirow{3}{*}{ Gora } & 1 & 0,42 \\
\hline & & 2 & Ttd \\
\hline & & 3 & 0.03 \\
\hline & \multirow{3}{*}{ Baronang kuning } & 1 & 0.06 \\
\hline & & 2 & Ttd \\
\hline & & 3 & Ttd \\
\hline & \multirow{3}{*}{ Capungan } & 1 & 0.07 \\
\hline & & 2 & 0.19 \\
\hline & & 3 & 0.12 \\
\hline \multirow{9}{*}{ Utara TM } & \multirow{3}{*}{ Gora } & 1 & Ttd \\
\hline & & 2 & 0.02 \\
\hline & & 3 & 0.09 \\
\hline & \multirow{3}{*}{ Baronang kuning } & 1 & 0.10 \\
\hline & & 2 & Ttd \\
\hline & & 3 & Ttd \\
\hline & \multirow{3}{*}{ Capungan } & 1 & Ttd \\
\hline & & 2 & 0.05 \\
\hline & & 3 & 0.09 \\
\hline
\end{tabular}

Keterangan : ttd : tidak terdeteksi

Dari hasil analisis laboratorium pada ketiga jenis ikan yang ditangkap mempunyai kandungan merkuri yang bervariasi, yaitu; untuk ikan Gora ( $M$. hexagona) di bagian Selatan Teluk Manado nilainya mulai dari $0.03 \mathrm{ppm}-$ $0.42 \mathrm{ppm}$; sedangkan bagian Utara mempunyai nilai mulai dari $0.02 \mathrm{ppm}-$ $0.09 \mathrm{ppm}$. Untuk ikan Baronang kuning (S. virgatus) di bagian Selatan Teluk Manado yaitu $0.06 \mathrm{ppm}$, dan untuk bagian Utara mempunyai nilai $0.10 \mathrm{ppm}$. Sedangkan pada ikan Capungan ( $A$. compressus) di bagian Selatan Teluk Manado mempunyai nilai mulai dari 0.07 ppm -0.19 ppm, dan pada bagian Utara TM mempunyai nilai 0.05 ppm - 0.09 ppm. Dari delapan belas ikan sampel, tujuh diantaranya tidak terdeteksi kandungan merkuri. Perbedaan kandungan $\mathrm{Hg}$ dalam tubuh hewan uji disebabkan oleh kemampuan serapan biota terhadap logam yang berbeda, dan sangat tergantung pada ukuran dan sifat makan organisme. Perbandingan konsentrasi merkuri $(\mathrm{Hg})$ yang diperoleh setelah analisis laboratorium, secara jelas ditampilkan dalam bentuk grafik batang seperti pada Gambar 1 .

Dalam Tabel 2 dan Gambar 1 diperlihatkan bahwa kandungan $\mathrm{Hg}$ tertinggi ditemukan pada ikan Gora $(M$. hexagona) (0.43 ppm) dan urutan tertinggi kedua terdapat pada ikan Capungan (A. compressus) (0.3 ppm). Hal ini diduga dipengaruhi oleh sifat makan karnivora dari kedua jenis ikan ini. Menurut Rudi dan Muchsin (2011), anggota dari family Holocintridae dan Apogonidae termasuk ikan karang yang aktif mencari makan atau aktif beraktifitas di malam hari. Konsentrasi $\mathrm{Hg}$ terendah ditemukan pada famili Siganidae, yaitu ikan Baronang kuning (S. virgatus) (0.1 ppm), yang tergolong herbivor dan juga ikan diurnal. Hasil analisis laboratorium, 


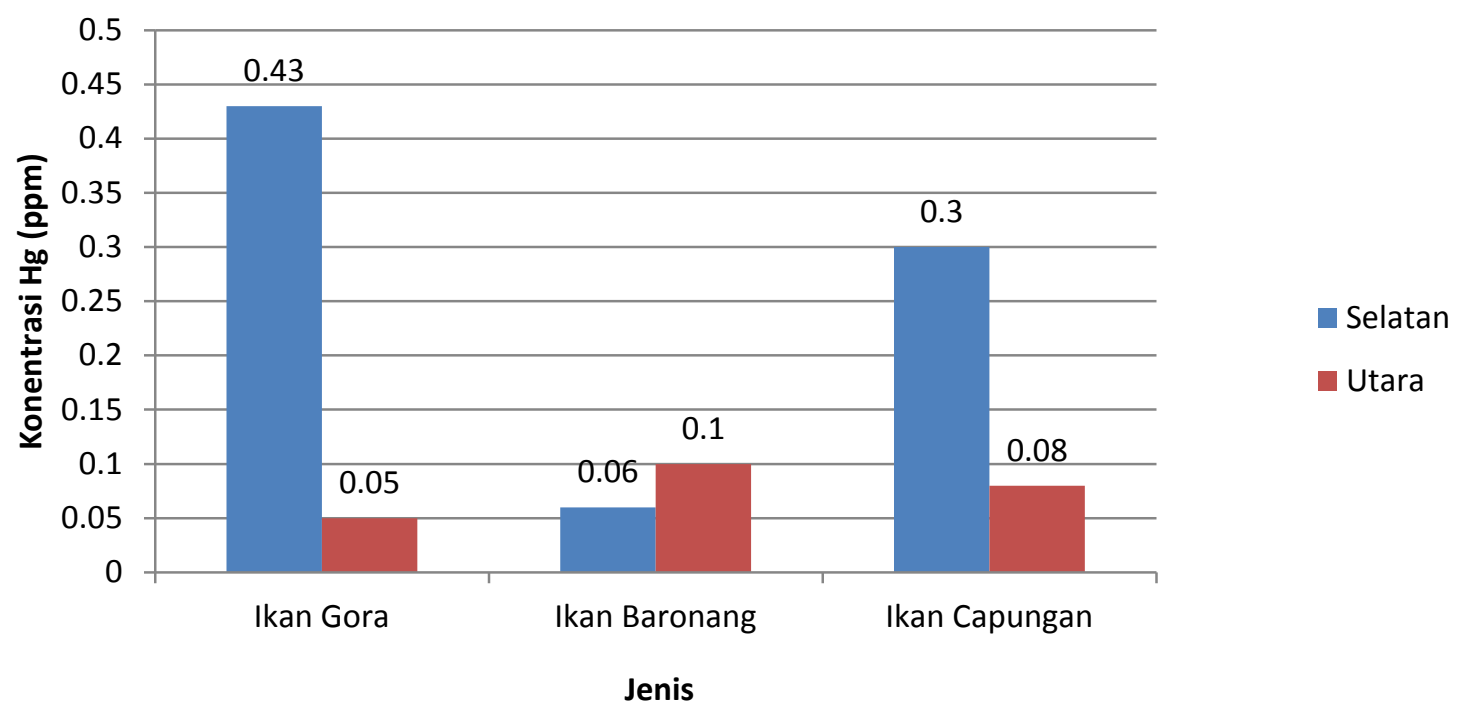

Gambar 1. Konsentrasi rata-rata merkuri dalam daging dari tiga jenis sampel ikan yang ditangkap di Selatan dan Utara perairan Teluk Manado.

kandungan merkuri dalam daging ikan yang dijadikan sampel, yang ditangkap di bagian Selatan dan Utara perairan Teluk Manado dalam penelitian ini, masih berada dibawah konsentrasi yang direkomendasikan WHO (0.5 ppm) untuk makanan. Kandungan logam berat pada ikan bersumber dari lingkungan perairan yang sudah terkontaminasi oleh logam berat. Kontaminasi lingkungan perairan tidak terlepas dari daratan aktifitas manusia di darat maupun pada perairan (Suyanto, 2010).

Pada umumnya, potensi akumulasi menunjukkan bahwa semakin tinggi rantai makanan maka akumulasi organisme tersebut terhadap logam berat semakin tinggi yang dihasilkan dengan semakin tinggi konsentrasi logam yang terkandung di dalam tubuh organisme tersebut. Hal tersebut dapat saja terjadi karena bertambahnya waktu, Menurut (Palar, 2008) proses transformasi ion metil merkuri dalam sistem rantai makanan mengalami pelipat-gandaan. Konsentrasi dari ion metil merkuri yang masuk dan terakumulasi dalam jaringan biota terus meningkat seiring dengan sistem rantai makanan. Sehingga biota seperti ikan-ikan besar yang telah memakan ikan-ikan yang lebih kecil yang telah terkontaminasi oleh metil merkuri, disinyalir mempunyai kandungan merkuri dalam jaringan biota perairan sesuai pula dengan proses biomaknifikasi yang terjadi dalam linkungan perairan. Namun hal ini tidak terjadi pada ketiga jenis ikan yang diambil dari dua lokasi tersebut. Hal ini diduga disebabkan oleh kemampuan absorbsi dan bioakumulasi dari ketiga jenis ikan ini berbeda.

Menurut Rudi dan Muchsin (2011), ikan Gora (M. hexagona) dan ikan Capungan (A. compressus) mempunyai sifat yang sama, dari sistem rantai makanan kedua ikan ini termasuk ikan karnivora, sedangkan ikan Beronang kuning ( $S$. virgatus) tergolong dalam ikan herbivor. Kandungan logam berat pada ikan bersumber dari lingkungan perairan yang sudah terkontaminasi oleh logam berat. Kontaminasi lingkungan perairan tidak terlepas dari daratan aktifitas manusia di darat maupun pada perairan (Suyanto, 2010). 
Merkuri dapat masuk ke dalam tubuh organisme perairan melalui tiga cara yaitu: melalui rantai makanan, difusi permukaan kulit dan melalui insang. Dari ketiga cara tersebut, yang paling besar kemungkinan untuk masuknya merkuri ke dalam tubuh adalah melalui rantai makanan, karena hampir $90 \%$ dari bahan beracun ataupun logam berat merkuri masuk ke dalam tubuh. Pada proses ini, fitoplankton memegang peranan penting di mana fitoplankton akan menyerap merkuri organik pada waktu berlangsungnya fotosintesis. Merkuri merupakan zat yang lipofilik di mana dengan sifat ini merkuri mudah berdifusi melewati membran kulit kemudian masuk kedalam jaringan tubuh (Palar, 2012; Akhadi, 2014).

Menurut Lodenius \& Malm (1998) dalam Simbolon dkk (2010) bahwa kandungan logam berat yang tinggi ditemukan pada kelompok ikan karnivora dan kemudian disusul oleh ikan pemakan plankton (planktivora) dan omnivor. Hasil penelitian ini menujukkan nilai kandungan merkuri tertinggi pada ikan Gora ( $M$. hexagona), ikan Capungan ( $A$. compressus) yang termasuk dalam ikan karnivora, nilai terendah terdapat pada ikan Beronang kuning ( $S$. virgatus) yang termasuk ikan herbivor. Nampak bahwa akumulasi merkuri pada ikan karnivora secara bioakumulasi melalui rantai makanan dapat terjadi di lingkungan perairan dari kelompok organisme produsen ke kelompok konsumen tingkat yang lebih tinggi. Bioakumulasi $\mathrm{Hg}$ pada ikan merupakan proses yang rumit dan belum dipahami sepenuhnya (Paarvita, 1991 dalam Lasut, 2009).

\section{KESIMPULAN}

adalah:

Kesimpulan dari penelitian ini

1. Merkuri tertinggi ditemukan pada ikan Gora ( $M$. hexagona) dengan nilai rata-rata $0.43 \mathrm{ppm}$, dan nilai tertinggi kedua yaitu pada ikan Capungan ( $A$. compresseus) dengan nilai rata-rata 0.3 ppm, sedangkan nilai terendah terdapat pada ikan Beronang kuning (S. virgatus) dengan nilai rata-rata 0.1 ppm. Konsentrasi merkuri $(\mathrm{Hg})$ tertinggi ditemukan pada ikan dari lokasi bagian Selatan (Teluk Manado), dibandingkan pada jenis yang sama dari bagian Utara (Teluk Manado).

2. Kandungan merkuri pada ikan Gora ( $M$. hexagona), Capungan ( $A$. compresseus), dan Beronang kuning (S. virgatus) di perairan Teluk Manado, masih berada di bawah ambang batas maksimum yang ditetapkan WHO.

\section{DAFTAR PUSTAKA}

Akhadi, M. 2014. Isu Lingkungan Hidup, Graha IImu Yogyakarta.

Aninomous. 2011. Metode Ekstrasi dan Destruksi Sampel. Baristand

Lasut, M.T. 2009. Proses Bioakumulasi Merkuri ( $\mathrm{Hg})$ Pada Organisme Perairan di dalam Wadah Terkontrol, Jurnal Matematika dan Sains. Universitas Sam Ratulangi

Palar, H. 2008. Pencemaraan dan Toksikologi Logam Berat, Rineka Cipta Jakarta

Palar, H. 2012. Pencemaraan dan Toksikologi Logam Berat, Rineka Cipta Jakarta

Ridhowati, S. 2013. Mengenal Pencemaran Ragam Logam, Graha IImu Yogyakarta 
Rudi, Muchsin, 2011. Ikan Karang Perairan Aceh dan Sekitarnya, Lubuk Agung Bandung.

Simbolon, D.,. Simage., M.S.I., Wulandari, Y.S. 2010. Kandungan Merkuri dan Sianida pada Ikan yang Tertangkap dari Teluk Kao, Halmahera Utara. Tesis, Program Pascasarjana, Institut Pertanian Bogor, Vol. 15. (3) 126-134.

Suyanto. 2010. Residu Logam Berat lkan Dari Perairan Tercemar Di Pantai Utara Jawa Tengah. Jurnal Pangan dan Gizi. Universitas Muhamadiyah Semarang. vol 1.

Widowati, W., Sastiono. A., Rumampuk, R.J. 2008. Efek Toksikologi Logam, Andi Yogyakarta. 